\title{
最適アルキメデス螺線補間法*
}

\author{
丘華*1, 久保 明 雄*1 \\ 林長 軍 ${ }^{* 2}$, 黎 子 楖*3
}

\section{Optimal Interpolation of Archimedes's Spiral for NC Machining of Noncircular Contours}

\author{
Hua QIU*4, Akio KUBO, \\ Chang-Jun LIN and $\mathrm{Zi}-$ Ye LI
}

${ }^{* 4}$ Department of Mechanical Engineering, Kyushu Sangyo University,

2-3-1 Matsukadai, Higashi-ku, Fukuoka-shi, Fukuoka, 813-8503 Japan

\begin{abstract}
In NC machining of noncircular contours, where cutter is fed along a straight line intersecting perpendicularly the roration axis of work piece, the cutter path usually consists of Archimedes's spiral segments. From machining precision and efficiency point of view, a desired cutter path should be composed of the fewer segments as possible under the condition of satisfying the specified interpolation error limitation. In this paper, an optimal interpolation principle of Archimedes's spiral for planar curves is presented and then a practical algorithm is constructed. The segment number of the cutter path resulted from the algorithm not only is the fewest but also the interpolation accuracy agrees with the specified value. It is also evidenced that the profile error of machined contour corresponding to the cutter path is perfectly controlled within the desired value, i. e. the specified interpolation error value, through detailed analyses. The interpolation results of using the presented algorithm for machining disc cam profile are compared with those obtained by Nishioka's methods ${ }^{(3)}$. The comparison results sufficiently confirm the validity of the algorithm developed by the authors.
\end{abstract}

Key Words : Noncircular Contour Machining, Cutter Path, Optimal Interpolation, Archimedes's Spiral, Offset Curve, Interpolation Accuracy, Profile Error, Disc Cam

\section{1.}

回転板力ムのような非円形回転断面輪郭の加工法と して, CNC 輪郭研削法 ${ }^{(1),(2) や, ~ マ シ ニ ン ク ゙ セ ン タ 上 て ゙ ~}$ 回転テーブルを使用する方法 ${ }^{(3)}$ がある.この場合, ワ ークの回転運動に対して工具を半径方向に直線運動さ せ，輪郭形状を創り出す．輪郭加工用の NC プログラ ムの作成にあたっては一般的な手順として次のような 作業を行う．まず，加工しようとするワーク輪郭に工 具半径分だけのオフセットをかけ, 極座標形式の工具 中心の理論軌跡（以下これを理論工具経路と略す）を 求める. 次に, 理論工具経路上に適当な間隔で分割点 を取り，隣り合う 2 点間にワークの回転運動と工具の 直線運動を線形補間して亡具の移動経路（以下，理論

* 原稿受付 2003 年 4 月 25 日.

*1 正員, 九州産業大学工学部( 813-8503 福岡市東区松香台 2-3-1).

*2 正員, 福岡大学工学部 ( $\approx 814-0180$ 福岡市城南区七限 8-191).

*3 正員, 上越教育大学学校教育学部( $\boldsymbol{w}$ 943-8512 上越市山屋 敷 1)

E-mail : chiu@ip.kyusan-u.ac.jp
経路と区別するために，これをカッターパスと乎ぶ) を決め， NC データを作成する．したがって， 2 分割 点間のカッターパスはアルキメデス螺線となり, 全輪 郭加工のカッターパスはアルキメデス螺線の補間曲線 群（補間セグメント）からなる.

輪郭の加工精度や加工効率などを考慮すると, 指定 した補間精度が保証できれば，最も少ない補間セグメ ントで構成するカッターパスが望ましい(2),(3).この問 題について, 西岡は, 回転板力ムの輪郭加工を対象と して, 指定した補間精度を保証する前提の下でセグメ ントの数を抑えるカッターパスの生成法を提案した ${ }^{(3)}$. この方法によれば, 従来の方法に比べて補間セグメン トの数を大幅に減少することができるが，生成された カッターパスは最適なものとはいえない. すなわち, 指定された補間精度に対して, 補間セグメントの数は 必要最小限の数をはるかに超えている. また, 文献(3) において，アルキメデス螺線補間によって加工された 輪郭の形状が多角形になることの説明はあったが, カ ッターパスの補間誤差と加工された輪郭の形状誤差と の関係については検討していない.

最近, 直線と円弧からなる輪郭の加工については, 
CNC 装置内部の極座標補間機能を利用すれば工具経 路のアルキメデス螺線補間を比較的容易に行うことが できるようになっている(4). しかし，その補間アルゴ リズム及び加工された輪郭の形状誤差などについては 明らかにされていない.

そこで, 本研究では, 平面曲線の最適アルキメデス 螺線補間の原理を明らかにした上で，指定された補間 精度を保証しながら，必要な補間セグメントの数を最 小限に抑えることができる NCカッターパスの生成法 を提案する．また，提案した方法によるカッターパス の補間誤差とそれに対応する加工輪郭の形状誤差との 関係についても詳細に検討し，その結果に基づいて加 エされた輪郭の形状精度が指定した補間精度以内に保 証されることを明らかにする．さらに，板カムの輪郭 加工問題に提案方法を適用し，その結果から提案した 方法の有効性を示す.

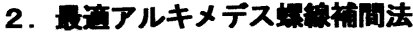

2・1 アルキメデス蜢图１に示すように， 一般的にアルキメデス螺線は次式で表せる。

$$
\rho=a \theta+b
$$

ここで, $\rho$ と は極半径と偏角であり, $a(a \neq 0)$ と $b$ は 定数である. 式(1)を直角座標の形に書き直すと,

$$
\left\{\begin{array}{l}
x=\rho \cos \theta=(a \theta+b) \cos \theta \\
y=\rho \sin \theta=(a \theta+b) \sin \theta
\end{array}\right.
$$

となり，接線の傾き $\mathrm{d} y / \mathrm{d} x$ は次式となる.

$$
\mathrm{d} y / \mathrm{d} x=\tan \left\{\theta+\tan ^{-1}(\theta+b / a)\right\}
$$

2-2 理埧経路 連続な平面曲線輪郭 $\boldsymbol{r}_{c}(t)$ (以下,これを理論輪郭と呼ぶ)を次式で与えるとする.

$$
r_{c}(t)=\left\{x_{c}(t), y_{c}(t), 0\right\} \quad\left(t_{s} \leq t \leq t_{E}\right)
$$

ここで, $t$ は曲線パラメータである.この輪郭を半径 $r_{t}$ の工具で加工する場合, 輪郭に固定する座標系にお ける理論工具経路 $\left\{x_{t}(t), y_{r}(t), 0\right\}$ は次式となる(5) (図 2 を 参照).

$$
\left\{\begin{array}{l}
x_{t}(t)=x_{c}(t)+\frac{k_{1} k_{2} r_{t} y_{c}^{\prime}(t)}{\sqrt{x_{c}^{\prime 2}(t)+y_{c}^{\prime 2}(t)}} \\
y_{t}(t)=y_{c}(t)-\frac{k_{1} k_{2} r_{t} x_{c}^{\prime}(t)}{\sqrt{x_{c}^{\prime 2}(t)+y_{c}^{\prime 2}(t)}}
\end{array}\right.
$$

ここで,'は $t$ に関する微分を意味する. 符号係数 $k_{1}$ と $k_{2}$ の值については, $t$ の増加にしたがって理論輪郭 が反時計まわりの場合に $k_{1}=1$, 時計まわりの場合に $k_{1}=-1$ とし, 理論輪郭に対して工具がその外側に位置 する（軸加工に相当）の場合に $k_{2}=1$ ，内側に位置する （穴加工に相当）の場合に $k_{2}=-1$ とする. また, 工具 半径 $r_{t}$ の値は理論輪郭の中凹部分の最小曲率半径より

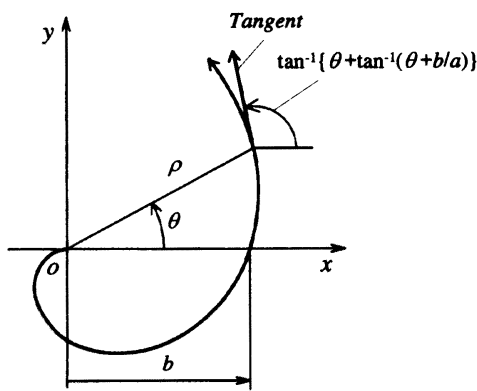

Fig. 1 Archimedes's spiral

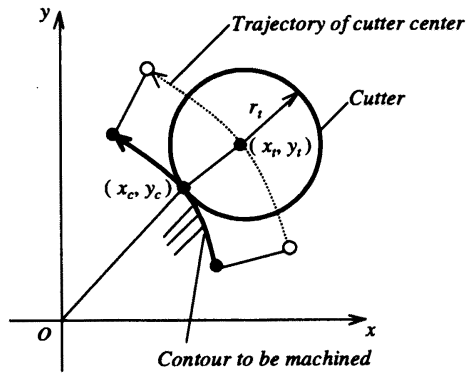

Fig. 2 Trajectory of cutter center for contour machining

大きくならないとする．なお，式の表現を簡潔にする ために，以下では，誤解を起こさない限り， $x_{r}(t)$ を $x_{t}$, $x_{t}^{\prime}(t)$ を $x_{t}^{\prime}$ のように簡単に記述する．理論工具経路の極 半径を $\rho_{r}(t)$, 偏角を $\theta_{r}(t)$ とすると, 次の式が得られる.

$$
\left\{\begin{array}{l}
\rho_{t}=\sqrt{x_{t}^{2}+y_{t}^{2}}=\sqrt{x_{c}^{2}+y_{c}^{2}+r_{t}^{2}+\frac{2 k_{1} k_{2} r_{t}\left(x_{c} y_{c}^{\prime}-x_{c}^{\prime} y_{c}\right)}{\sqrt{x_{c}^{\prime 2}+y_{c}^{\prime 2}}}} \\
\theta_{t}=\tan ^{-1}\left(y_{t} / x_{t}\right)=\tan ^{-1}\left(\frac{y_{c} \sqrt{x_{c}^{\prime 2}+y_{c}^{\prime 2}}-k_{1} k_{2} r_{t} x_{c}^{\prime}}{x_{c} \sqrt{x_{c}^{\prime 2}+y_{c}^{\prime 2}}+k_{1} k_{2} r_{t} y_{c}^{\prime}}\right) \\
\frac{d^{2} \rho_{t}}{d \theta_{t}^{2}}=\frac{\theta_{t}^{\prime} \rho_{t}^{\prime \prime}-\theta_{t}^{\prime \prime} \rho_{t}^{\prime}}{\theta_{t}^{\prime 3}}
\end{array}\right.
$$

一方, CNC 輪郭研削法や, 回転テーブルを使用す るマシニングセンタによる非円形断面の輪郭加工には, ワークを一方向だけ回転させるのは普通である ${ }^{(1)-(3)}$. その点を考慮して, 本研究では, 式(4)の理論輪郭と式 (5)の理論工具経路に対しては,それらがともに座標原 点からの任意な半直線との交点を一つだけ持つという 制限を加える.

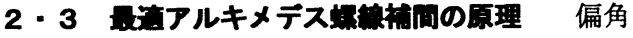
を横座標, 極半径を縦座標とする直角座標系（以下， $\theta$ - $\rho$ 座標系と呼ぶ) に式(6)で記述する理論工具経路を 描くと，一般的に図 3 に示すような形になる。 すなわ ち, 理論経路はいくつかの下に凸の領域 $\left(\mathrm{d}^{2} \rho_{t} / \mathrm{d} \theta{ }_{t}{ }^{2}>0\right.$ の領域. 以下, 単に凸領域と呼ぶ) と下に凹の領域 $\left(\mathrm{d}^{2} \rho_{t}\right.$ $/ \mathrm{d} \theta_{t}{ }^{2}<0$ の領域. 以下，単に凹領域と呼ぶ）からなる. 


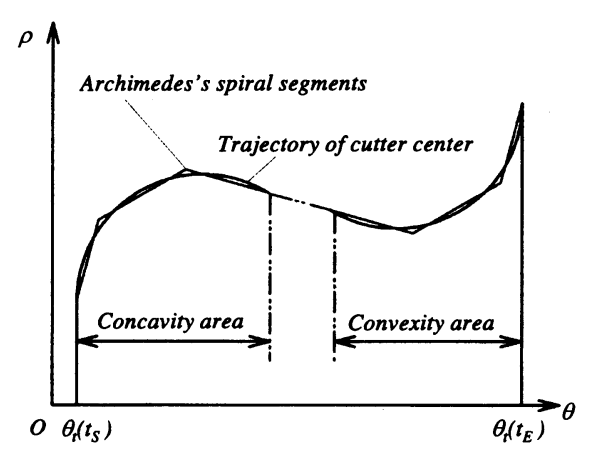

Fig. 3 Trajectory of cutter center and Archimedes's spiral segments in the polar coordinates

一方, 式(1)に示すように, $\theta$ - $\rho$ 座標系においてアルキ メデス螺線は直線の形となる. したがって, $\theta$ - $\rho$ 座標 系における理論工具経路の近似直線群（補間セグメン ト）は輪郭加工におけるカッターパスとなる. 明らか に, 補間セグメントの数を少なくするには, 一つの補 間セグメントと理論工具経路との交点を二つにするべ きである.

本研究では, 補間セグメント上の点の補間誤差を, この点を通る理論工具経路の法線にそって理論工具経 路までの距離とする. また, 補間セグメントが理論工 具経路の外側に位置するとき, 補間誤差の值を正, 内 側に位置するときは負とする. なお，次章に説明する 加工輪郭の形状誤差と付録に説明する法線方向距離の 值の正負についても同様に定義する.

付録に示すように, アルキメデス螺線と， $\theta$ - $\rho$ 座標 系における凹または凸になる曲線との間に, 補間誤差 の極值点は一つだけである. そのため, 一つの補間セ グメントとそれに対応する理論工具経路の部分との間 に, 補間誤差の極值点は三つとなる. すなわち, 接線 方向が理論工具経路上の対応点のそれに平行となる補 間セグメント上の点, 及び補間セグメントの両端点で ある. したがって, これらの極值点での補間誤差の值 を指定した補間精度の值に一致させるように, 各補間 セグメントを定めれば, 最適なカッターパスは得られ る.

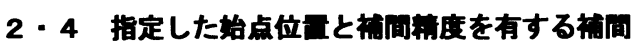
セグメントの決め方 同一凹凸領域における理論 工具経路と, それに対応する一つの補間セグメントと の関係を図 4 に示す. 補間セグメントの始点 $A$ は, 理 論工具経路上の既知点 $S$ (それに対応する曲線パラメ 一夕を $t_{0}$ とする）の法線上の点として指定される. 補 間セグメント上の点 $\boldsymbol{B}$ は補間誤差極值点であり, その 補間誤差の絶対值が指定された補間精度の值 $\boldsymbol{e}$ に等し

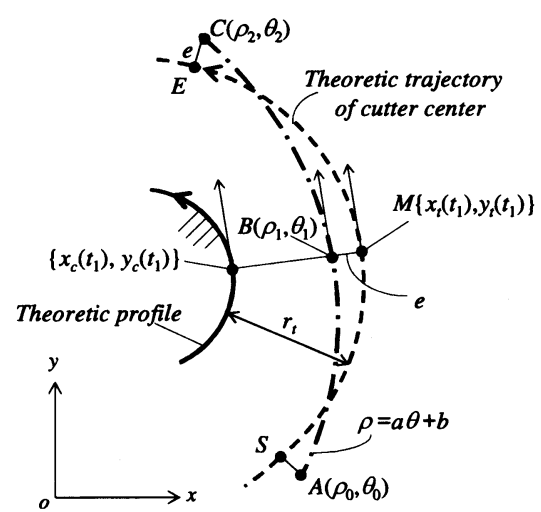

Fig. 4 Determination of Archimedes's spiral segment

い. 補間セグメントの終点 $C$ の補間誤差の絶対値も $e$ に等しい. また, 点 $A, B, C$ の極座標をそれぞれ $\left(\rho_{0}, \theta_{0}\right)$, $\left(\rho_{1}, \theta_{1}\right),\left(\rho_{2}, \theta_{2}\right)$ とする.

補間セグメントは点 $A$ と点 $B$ を通るアルキメデス螺 線であるので, そのパラメータ $a$ と $b$ が次式による.

$$
\left\{\begin{array}{l}
a=\left(\rho_{1}-\rho_{0}\right) /\left(\theta_{1}-\theta_{0}\right) \\
b=\left(\rho_{0} \theta_{1}-\rho_{1} \theta_{0}\right) /\left(\theta_{1}-\theta_{0}\right)
\end{array}\right.
$$

ただし， $\rho_{1}$ と $\theta_{1}$ は次式を満足する.

$$
\left\{\begin{array}{l}
\rho_{1}=\sqrt{x^{2}\left(t_{1}\right)+y^{2}\left(t_{1}\right)} \\
\theta_{1}=\tan ^{-1}\left\{y\left(t_{1}\right) / x\left(t_{1}\right)\right\} \\
x\left(t_{1}\right)=x_{c}\left(t_{1}\right)+\frac{k_{1} k_{2}\left(r_{t} \pm e\right) y_{c}^{\prime}\left(t_{1}\right)}{\sqrt{x_{c}^{\prime 2}\left(t_{1}\right)+y_{c}^{\prime 2}\left(t_{1}\right)}} \\
y\left(t_{1}\right)=y_{c}\left(t_{1}\right)-\frac{k_{1} k_{2}\left(r_{t} \pm e\right) x_{c}^{\prime}\left(t_{1}\right)}{\sqrt{x_{c}^{\prime 2}\left(t_{1}\right)+y_{c}^{\prime 2}\left(t_{1}\right)}}
\end{array}\right.
$$

ここで, 複号は凸領域の場合が上, 凹領域の場合が下 である. また, 点 $\boldsymbol{B}$ の接線が理論工具経路及び理論輪 郭上の対応点での接線と平行になるので, 次の式が成 立する.

$f_{1}\left(t_{1}\right) \equiv y_{c}^{\prime}\left(t_{1}\right)-x_{c}^{\prime}\left(t_{1}\right) \tan \left\{\theta_{1}+\tan ^{-1}\left(\theta_{1}+b / a\right)\right\}=0$ したがって, $t_{1}=t_{0}+\Delta t$ のように, $t_{1}$ に適当な初期值を 与え, 式(8)〜 (10) を通して式(10)を数值的に解くと, $t_{1}$ 及び補間セグメントのパラメータ $a$ と $b$ の值を定め ることができる.

一方, 補間セグメント終点 $C$ の座標は次式で表され る.

$$
\left\{\begin{array}{l}
\rho_{2}=\sqrt{x^{2}\left(t_{2}\right)+y^{2}\left(t_{2}\right)} \\
\theta_{2}=\tan ^{-1}\left\{y\left(t_{2}\right) / x\left(t_{2}\right)\right\} \\
x\left(t_{2}\right)=x_{c}\left(t_{2}\right)+\frac{k_{1} k_{2}\left(r_{t} \mp e\right) y_{c}^{\prime}\left(t_{2}\right)}{\sqrt{x_{c}^{\prime 2}\left(t_{2}\right)+y_{c}^{\prime 2}\left(t_{2}\right)}} \\
y\left(t_{2}\right)=y_{c}\left(t_{2}\right)-\frac{k_{1} k_{2}\left(r_{t} \mp e\right) x_{c}^{\prime}\left(t_{2}\right)}{\sqrt{x_{c}^{\prime 2}\left(t_{2}\right)+y_{c}^{\prime 2}\left(t_{2}\right)}}
\end{array}\right.
$$


また, 点 $C$ に対して次式が成立する.

$$
f_{2}\left(t_{2}\right) \equiv \rho_{2}-\left(a \theta_{2}+b\right)=0
$$

よって, $t_{2}=t_{1}+\Delta t$ のように, $t_{2}$ に適当な初期值を与え，

式(12)を数值的に解くと, 補間セグメント終点 $C$ に対 応する曲線パラメータ $t_{2}$ の值及び終点 $C$ の位置 $\left(\rho_{2}, \theta_{2}\right)$ を定めることができる.

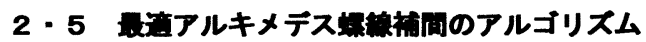

まず，曲線パラメータ $t$ の適当な間隔で，理論輪郭 の式と使用工具の半径から理論工具経路を求める. 同 時に,式(7)を利用して理論工具経路の凹凸性を判別し， 凹凸領域を決める．次に，凹凸の領域ごとに補間を行 う.ただし，領域間の接続を容易に行うためには，各 領域の 1 番目のセグメントの始点を領域の始点に, 最 後のセグメントの終点を領域の終点にそれぞれ一致す るように指定する. 補間アルゴリズムは次のようにな る.

(a) セグメントの終点位置が補間領域の終点位置に 一致するように, 式(8)〜 (12)を用いて, 最後の補間セ グメントのパラメータ $a_{e}$ と $b_{e}$, セグメントの始点に対 応する曲線パラメータ $t_{e}$ の值及び始点の極座標 $\left(\rho_{e}, \theta_{e}\right)$ を求める. $i=0$ とする.

(b) $i=i+1$ とし, 補間領域の始点（ $i=1$ の場合）または $i-1$ 番目補間セグメントの終点を始点（ $i \neq 1$ の場合）と して, 式(8)〜 (10)により $i$ 番目補間セグメントのパラ メータ $a_{i}$ と $b_{i}$, 中間補間誤差極值点に対応する曲線パ ラメータ $t_{i 1}$ を求める. $t_{i 1} \geq t_{e}$ なら(d)へ. そうでないと(c) ก.

(c) 式(11)と(12)を用いて， $i$ 番目補間セグメント終 点に対応する曲線パラメータ $t_{i 2}$ と終点の極座標を求め る. $t_{i 2} \geq t_{e}$ なら $(\mathrm{d})$ ). そうでないと, 終点の極座標を $\left(\rho_{i}\right.$, $\left.\theta_{i}\right)$ とし, (b)へ.

(d) $i=i+1$ とし, $a_{i}=a_{e}, \quad b_{i}=b_{e}$ のように, $i$ 番目補間セ グメントのパラメータを定め, 次式により $i$ 番目と $i-1$ 番目補間セグメントの交点の極座標 $\left(\rho_{i-1}, \theta_{i-1}\right)$ を決める.

$$
\left\{\begin{array}{l}
\rho_{i-1}=\left(a_{i-1} b_{i}-a_{i} b_{i-1}\right) /\left(a_{i-1}-a_{i}\right) \\
\theta_{i-1}=\left(b_{i}-b_{i-1}\right) /\left(a_{i-1}-a_{i}\right)
\end{array}\right.
$$

(e) 理論工具経路の次の凹凸領域に進むs.

本アルゴリズムでは, 補間計算を円滑に行うために, ステップ(a)と(d)を組み込んでいる. ステップ(d)に定 めた $i-1$ 番目と $i$ 番目の補間セグメントは, 理論工具 経路との交点が一つになったり, 互いの交点における 補間誤差の絶対值が指定された補間精度値より小さく なることがあり得る. しかし, 指定した補間精度を保 証しながら得られた補間セグメントの数が最も少ない という前提条件にとってはまったく変わりがない.

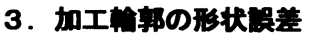

\section{3・1 䘞同セグメントに対応する加工韩の形状} 略差の特図 5 に補間セグメント $(\rho=a \theta+b)$ と 加工された輪郭の形状誤差の関係を示す. 工具半径 $r_{t}$ だけ離れた補間セグメントのオフセット曲線は加工さ れた輪郭となる. 補間セグメントの両端点と内部の補 間誤差極値点をそれぞれ $A, B, C$ とし, それに対応する 加工輪郭上の点をそれぞれ $D, E, F$ とする．点 $B$ に対 応する理論工具経路上の点を $G$, 理論輪郭上の点を $H$ とすると，点 $B, G, E, H$ はともに点 $G$ における理論工 具経路の法線上にある. オフセット曲線の性質(5)から， 点 $B, G, E, H$ における各曲線の接線が互いに平行とな $\eta$, 点 $E$ と点 $H$ との間の距離は点 $B$ と点 $G$ との間の 距離と等しくなる.つまり, 加工された輪郭上の点 $E$ は形状誤差の極值点であり，その形状誤差の絶対値は 指定された補間精度の值 $\boldsymbol{e}$ と等しい.

一方, 端点 $D$ と $F$ を除いた加工輪郭の内部において は, 形状誤差の極值点が点 $E$ のみであることが証明で きる. すなわち，加工輪郭の内部に別の形状誤差の極 值点 $E_{1}$ が存在するとすれば，点 $E_{1}$ が理論輪郭上の対 応点 $H_{1}$ の法線上にあり, 点 $E_{1}$ と点 $H_{1}$ における加工輪 郭と理論輪郭の接線が平行している. また, 点 $H_{1}$ にお ける理論輪郭の法線が理論工具経路及び補間セグメン トとの交点を $G_{1}$ と $B_{1}$ とすると, オフセット曲線の性 質(5)から，点 $B_{1}$ における補間セグメントの接線と点 $G_{1}$ における理論工具経路の接線が平行となり, 点 $B_{1}$ は点 $B$ と同じように補間セグメント内部の補間誤差極 值点となる．しかし，付録の結論によれば，これはあ りえないことである．したがって，加工輪郭の内部に おいて, 点 $E$ 以外の形状誤差の極值点は存在しない. 以上の説明から，補間セグメントによる加工輪郭と

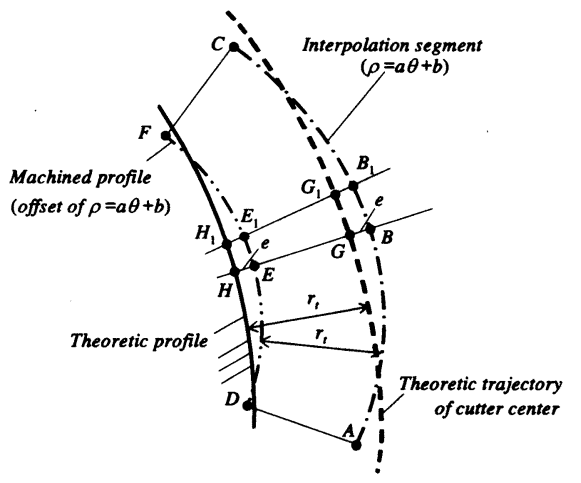

Fig. 5 Profile error of machined contour by interpolation segment 
理論輪郭との間に, 端点を含め形状誤差の極値点は三 つしか持っていないことと，端点でない形状誤差の極 值点における形状誤差の絶対值は指定された補間精度 の值に等しいことがわかった．したがって，端点にお ける形状誤差の值がわかれば, 加工輪郭の形状誤差值 の変動範囲はわかる.

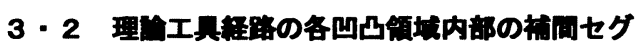

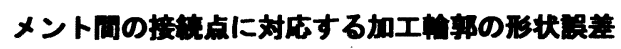

(1) 凸领城の场合理論工具経路の凸領域内部に おける二つの補間セグメントの接続点に対応する加工 輪郭の形状誤差を図 6 に示す. $i$ 番目と $i+1$ 番目の補間 セグメントの接続点を $B$ とし, 点 $B$ を通る理論工具経 路の法線が理論工具経路と理論輪郭との間にそれぞれ 点 $A$ と点 $C$ で交わるとする. また, $i$ 番目補間セグメ ントのオフセット曲線の終点を $E, i+1$ 番目補間セグメ ントの始点を $F$ とする. 点 $E$ と点 $F$ は, 互いに離れて いるが, 中心が点 $B$ で半径が工具半径 $r_{t}$ の円周上にあ る. したがって, 加工された輪郭は, 互いに滑らかに 接続している $i$ 番目補間セグメントのオフセット曲線, 円弧 $E D F$ 及び $i+1$ 番目補間セグメントのオフセット曲 線からなっている. 補間セグメントの接続点 $B$ に対応 する加工輪郭は過渡円弧 $E D F$ となる。点 $D$ は点 $A$ を 通る理論工具経路の法線と過渡円弧との交点である. 2 本の連続曲線に対して，一方の法線にそって測った 両曲線間の距離（法線方向距離）は, 共通法線を持つ 両曲線上の点の間にしか極值が現われないので, 点 $D$ は理論輪郭に対する加工輪郭上の形状誤差の極值点で ある. 一方, 図6からわかるように, 点 $C$ と点 $D$ との 間の距離は点 $A$ と点 $B$ との間の距離に等しい. したが って, 式(11)と（12）によって定まった補間セグメント の接続点に対応する加工輪郭の最大形状誤差の絶対值 は指定された補間精度の值 $e$ となり, 式(13)によって 定まった補間セグメントの接続点に対応する加工輪郭 の最大形状誤差の絶対值は $e$ を超えないことがわかっ た.

(2) 凹埇城の合 理論工具経路の凹領域内部に おける二つの補間セグメントの接続点に対応する加工 輪郭の形状誤差を図 7 に示す. 図中の点 $A, B, C, E, F$ の定義は図 6 のそれらと同じである. 図示したように, $i$ 番目と $i+1$ 番目補間セグメントのオフセット曲線は, 点 $E$ と点 $F$ との間に位置する点 $D$ で交わる. したがっ $\tau$, 加工された輪郭は, 点 $D$ を終点とする $i$ 番目補間 セグメントのオフセット曲線の部分と点 $D$ を始点とす る $i+1$ 番目補間セグメントのオフセット曲線の部分か らなっている. 点 $D$ は加工輪郭多角形の頂点となる.

一方, 図 7 に示したように, 点 $A$ を通る理論亡具経

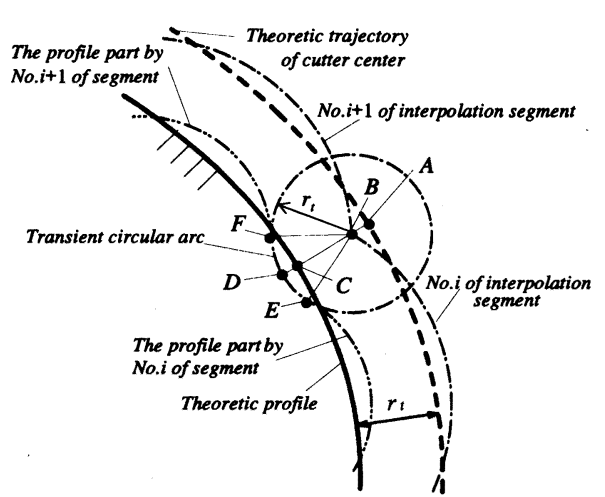

Fig. 6 Profile error of machined contour relative to an intersection between two segments in convexity area

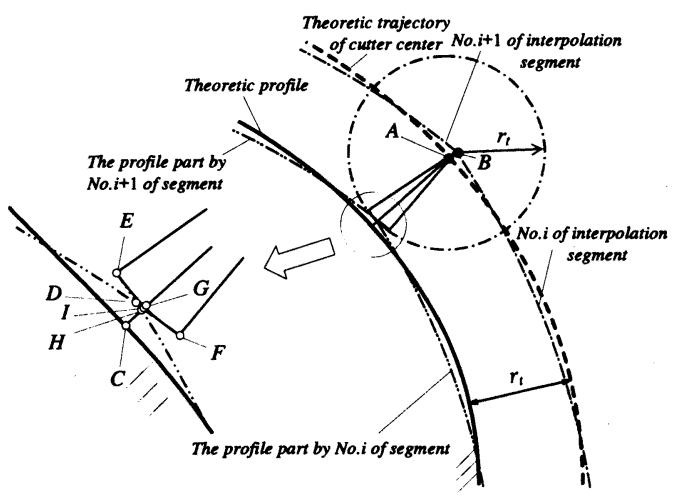

Fig. 7 Profile error of machined contour relative to an intersection between two segments in concavity area

路の法線を延ばすと, それは $i$ 番目と $i+1$ 番目補間セ グメントのオフセット曲線とそれぞれ点 $\boldsymbol{H}$ と点 $\boldsymbol{I}$ で交 わり, また, 中心が点 $B$ で半径が工具半径 $r_{t}$ の円と点 $G$ で交わる. 点 $C$ と点 $G$ との間の距離は点 $A$ と点 $B$ との間の距離に等しい. 図から明らかに次の関係が成 り立つ.

$$
\max \{\overline{C H}, \overline{C I}\}<\overline{C G}=e
$$

$3 \cdot 1$ 節の結論から, 点 $D$ での加工輪郭の形状誤差は, 点 $\boldsymbol{H}$ と点 $\boldsymbol{I}$ での形状誤差の大きい方（上式の左側）よ り值が小さいことがわかる. したがって，2 種類の接 続点（式(11)と (12)によるものと式(13)によるもの) に対応する加工輪郭の形状誤差の值は指定された補間 精度の值 $e$ より小さい.

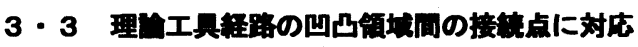
する加工和の形状競差理論工具経路の凸領域 と凹領域との接続点に対応する加工輸郭の形状誤差を 図8に示す. 図中の $i$ 番目補間セグメントは前の凸領 域の最後のセグメントであり, $i+1$ 番目補間セグメン 


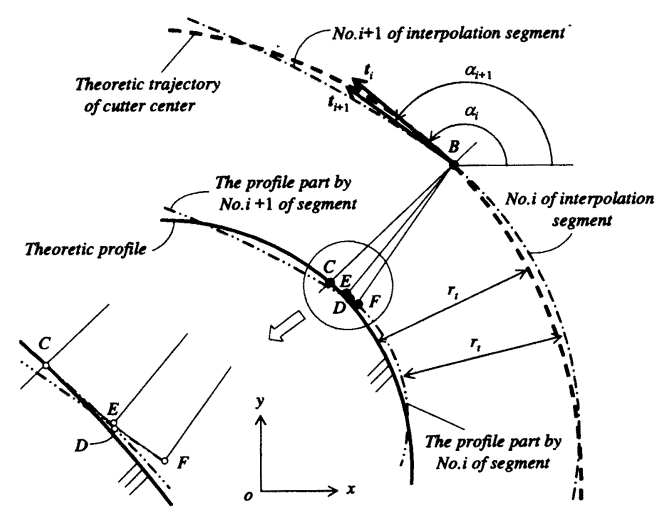

Fig. 8 Profile error of machined contour relative to an intersection between convexity area and concavity area

トは次の凹領域の 1 番目のセグメントである，両者の 接続点 $B$ は理論工具経路の領域間の接続点に一致して いる. 点 $B$ を通る理論工具経路の法線は理論輪郭と点 $C$ で交わる. $i$ 番目補間セグメントのオフセット曲線の 終点 $E$ と, $i+1$ 番目補間セグメントのオフセット曲線 の始点 $F$ は, 点 $C$ とともに中心が点 $B$ で半径が工具半 径 $r_{t}$ の円周上にある. 図中の $\boldsymbol{t}_{\boldsymbol{i}}$ と $\boldsymbol{t}_{i+1}$ はそれぞれ点 $B$ における $i$ 番目と $i+1$ 番目補間セグメントの接線ベク トルであり，それらの $x$ 軸の正方向に対する角度を $\alpha_{i}$ と $\alpha_{i+1}$ とする. $3 \cdot 2$ 節と同じ方法を使用して $i$ 番目 と $i+1$ 番目補間セグメントの違う接続状態について考 察すると，次の結論が容易に導かれる.

（1） $\alpha_{i+1}>\alpha_{i}$ の場合（図示した状態）における加工輪 郭は, 点 $D$ を終点とする $i$ 番目補間セグメントのオフ セット曲線の部分と点 $D$ を始点とする $i+1$ 番目補間セ グメントのオフセット曲線の部分からなっている.

(2) $\alpha_{i+1}=\alpha_{i}$ の場合における加工輪郭は, $i$ 番目と $i+1$ 番目補間セグメントのオフセット曲線が滑らかにつな がる形となる.

(3) $\alpha_{i+1}<\alpha_{i}$ の場合における加工輪郭は, $i$ 番目と $i+1$ 番目補間セグメントのオフセット曲線との間に中心が 点 $B$ で半径が工具半径 $r_{t}$ の過渡円弧によって滑らかに つながる形になる.

また，三つの場合においても，補間セグメントの接 続点に対応する加工輪郭の形状誤差の值は指定された 補間精度值 \pm 以内になる.

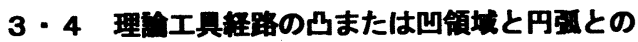

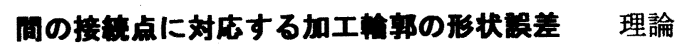
輪郭上に中心を座標原点に置く円弧部分があれば，そ れに対応する理論工具経路も同じ中心を持つ円弧とな る.このような円弧と理論工具経路の凸領域との接続 点の状態については, 図8における $i+1$ 番目補間セグ
メントを円弧として考え，また，四領域との接続につ いては, 図8における $i$ 番目補間セグメントを円弧と して考えれば良い.このような場合について，3・2 節と同じ方法を用いて加工輪郭の接続関俰を考察する と，次のような結論が容易に導かれる.

理論工具経路の凸領域の補間セグメントによる加工 輪郭は, 理論輪郭の円弧部分との間に, 半径 $r_{t}$ の過渡 円弧によって滑らかにつながっている. 凹領域の補間 セグメントのオフセット曲線が理論輪郭の円弧部分と 滑らかにつながらないが，接続点における加工輪郭の 形状誤差は0である.

以上では，工具が輪郭の外側を回って加工すること を前提にして加工された輪郭の形状誤差について説明 したが，工具が輪郭の内側を回る場合にも同じ結果が 導かれる. ただし, 加工輪郭の形状誤差の特徴は, 後 者の理論工具経路の凹領域の場合が前者の凸領域の場 合に，後者の凸領域の場合が前者の凹領域の場合にそ れぞれ対応している.

本章の結果をまとめると, 提案したアルゴリズムに よるカッターパスは,その自体の補間精度のみでなく, 加工された輪郭の形状精度も前もって指定した補間精 度值以内に抑えられることがわかった。

\section{4. 棫间约}

図 9 に示す円端直動従節回転力ムの輪郭加工を例と して, 提案した最適アルキメデス螺線補間法を適用し た. カム曲線は変形正弦曲線(6)を使い，ピッチ曲線の ベース円半径を $40 \mathrm{~mm}$, 従節ストロークを $30 \mathrm{~mm}$, カ ムの立ち上がり区間を $100^{\circ}$ とた. また, 計算中に工 具の半径を従節ローラの半径と同じにしたので, 理論 工具経路はカムのピッチ曲線と同一になる. カムの回 転角 $\theta$ を曲線パラメータとして用いると， $\theta=0^{\circ} \sim 50^{\circ}$ の 領域においてピッチ曲線は凸となり， $\theta=50^{\circ} \sim 100^{\circ}$ の領 域においては凹となる.

種々の補間精度値を指定して，ピッチ曲線のカム立 ち上がり区間（図 9 中の $A B$ 区間）に対する補間セグ

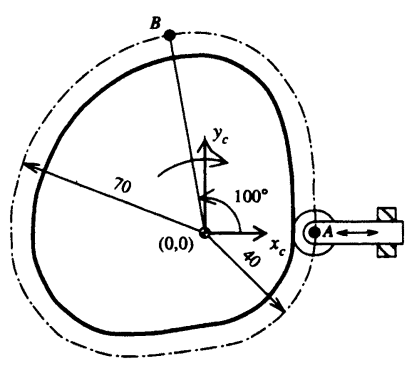

Fig. 9 Cam profile in the example 
Table 1 Interpolation results

\begin{tabular}{|c|c|c|}
\hline Interpolation method & Specified accuracy $(\mu \mathrm{m})$ & No. of segment \\
\hline \multirow{4}{*}{ The authors' method } & \pm 5 & 36 \\
\cline { 2 - 3 } & \pm 2 & 55 \\
\cline { 2 - 3 } & \pm 1 & 77 \\
\cline { 2 - 3 } & \pm 0.5 & 109 \\
\cline { 2 - 3 } & \pm 0.2 & 171 \\
\cline { 2 - 3 } & \pm 0.1 & 240 \\
\cline { 2 - 3 } & \pm 0.05 & 340 \\
\hline Nishioka's method 1 $^{(3)}$ & \pm 0.5 & 204 \\
\hline Nishioka's method 2 $^{(3)}$ & & 155 \\
\hline
\end{tabular}
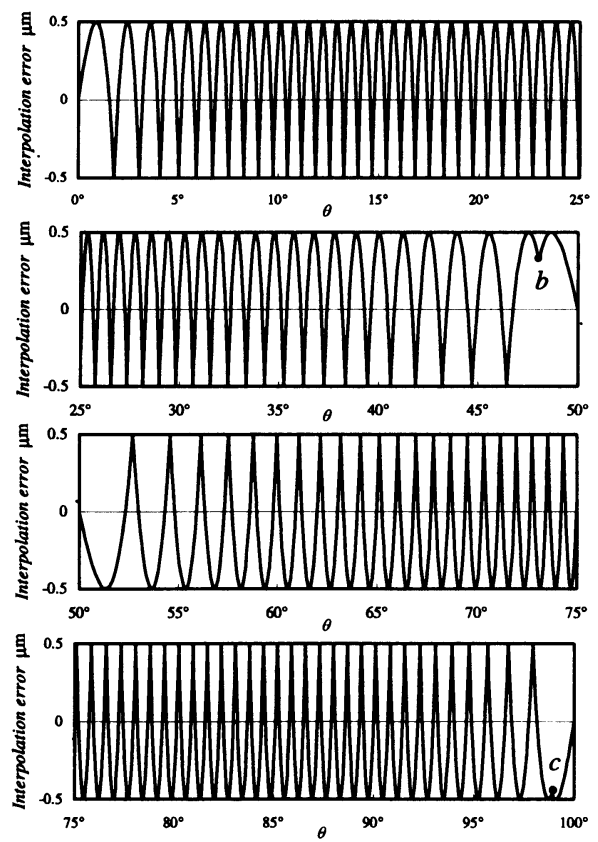

Fig. 10 Interpolation error of cutter path

メントの数を表 1 に示す. 表中には文献 (3)の結果も併 記している. 文献(3)の方法 1 は, ピッチ曲線に対して, 各セグメントの補間誤差の中で最も大きなものが指定 された值に一致するように, カムの回転角を等分割し て補間を行う方法である. 方法 2 は各セグメントにお ける最大補間誤差が指定された值に一致するように補 間を行う方法である. 表 1 の結果から，同じ補間精度 值に対して，提案した補間法による補間セグメントの 数は文献(3)の結果よりはるかに少ないことがわかる. また, 文献(3)に示した円端摇動従節回転力ムの輪郭加 エに対しても同じ結果になったことも確認された.

補間精度の值を $\pm 0.5 \mu \mathrm{m}$ に指定した場合に, ピッチ曲 線のカム立ち上がり区間に対する補間誤差曲線を図 10 に示す. 図中の点 $b$ と点 $c$ は式(13)による補間セグ メントの接続点である. 図 11 に工具半径を $12.5 \mathrm{~mm}$ に した場合の加工輪郭の形状誤差を示す.この図からわ
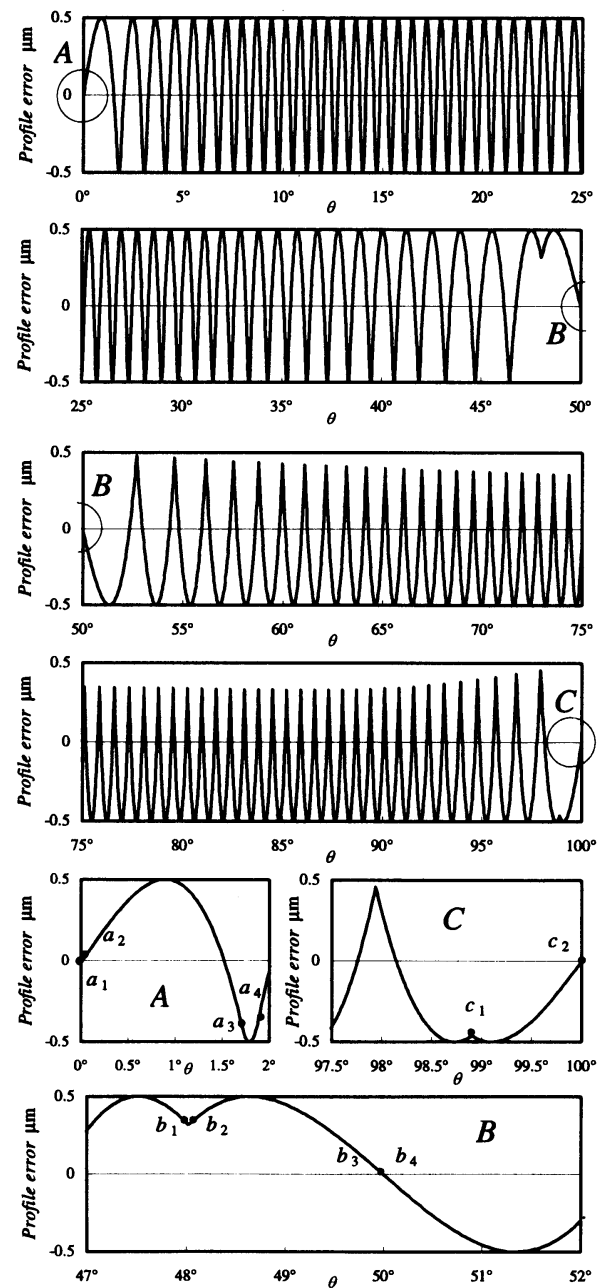

Fig. 11 Profile error of machined contour

かるように，加工輪郭の形状誤差は完全に指定した補 間精度值 $\pm 0.5 \mu \mathrm{m}$ 以内に抑えられている. また, ピッチ 線の凹領域に属する補間セグメント間の接続点に対応 する加工輪郭の形状誤差は指定した值 $0.5 \mu \mathrm{m}$ より若干 小さくなっている. 図中の点 $a_{1}$ と点 $a_{2}$ は輪郭の円弧部 分と 1 番目補間セグメントの加工部分をつなぐ過渡円 弧の端点, 点 $a_{3}$ と点 $a_{4}$ は 1 番目と 2 番目補閒セグメン トに対応する加工部分間の過渡円弧の端点, 点 $b_{1}$ と点 $b_{2}$ は図 10 の点 $b$ に対応する過渡円弧の端点, 点 $b_{3}$ と 点 $b_{4}$ はピッチ線の凸領域と凹領域の接続点 $(3 \cdot 3$ 節 の $\alpha_{i+1}<\alpha_{i}$ の場合に相当）に対応する過渡円弧の端点, 点 $c_{1}$ は図 10 の点 $c$ に対応する加工輪郭上の接続点, 点 $c_{2}$ は最後の補間セグメントによる加工輪郭の終点で ある. 図 11 の結果から，3 章に説明した加工輪郭の形 状誴差の特徴が確認された. 
提案した方法のプログラムは DIGITAL Visual Fortran 6.0 言語(倍精度)で作成され, 各例の補間計 算時間はすべて 0.05 秒以内であった (Epson Type-SJ 型パソコン : Pentium III CPU, 800MHz, 128MB).

\section{5.}

本研究においては, 回転 1 軸と直線 1 軸を同時制御 軸とする非円形回転断面の NC 輪郭加工を対象とし, 工具経路の最適アルキメデス螺線補間について検討し た。 その結果は次の通りである。

（1）平面曲線の最適アルキメデス螺線補間の原理を 明らかにした上で，指定された補間精度を保証しなが ら，必要な補間セグメントの数を最小限に抑えること ができる NC カッターパスの生成法を提案した.

（2）提案した方法によるカッターパスに対応する加 工輪郭の形状誤差について詳細に検討した. その結果, 加工された輪郭の形状精度は前もって指定した補間精 度以内に保証されることが明らかとなった。

（3）板カムの輪郭加工問題に提案した方法を適用し た結果, その有効性が確認された.

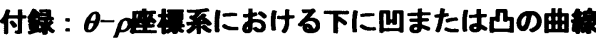

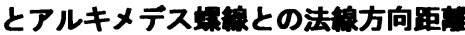

図 12 の(a)に $\theta-\rho$ 座標系における下に凹の曲線とア ルキメデス螺線 $\rho=a \theta+b$ を示す. また, 図中の点線は $\rho$ $=a \theta+b$ の平行線であり, $\rho=a \theta+b$ と同じ 1 次項係数 $a$ を持つアルキメデス螺線である.曲線が凹であるため, これらのアルキメデス螺線と曲線との間に交点があれ ば，その数は 2 個または 1 個である. 交点を囲む曲線 の左右部分は, 交点を通るアルキメデス螺線の上下両 側か下側のみかに位置し，上側のみに位置することが ありえない，以下，この凹曲線の法線にそって曲線か らアルキメデス螺線までの法線方向距離の值において, 最小值として 1 個のみ極值が存在することを示す.

まず，凹曲線とアルキメデス螺線との両交点の間に 法線方向距離の最大值点が存在することを仮定する.

そうすると, 図 12 の(a)における凹曲線とアルキメデ 螺線 $\rho=a \theta+b$ を $x-y$ 座標系に描くとき, (b)図のよう な形になる. すなわち, アルキメデス螺線上の点 $E$ は 法線方向距離の極大值点であり, 点 $E$ に対応する曲線 上の点は $D$ である. また, 点 $D$ で曲線と接するアルキ メデス螺線 $\rho=a \theta+c$ を描くことができる.これは，点 $E$ と点 $D$ における両アルキメデス螺線の接線が平行で あるから，次式よりパラメータcの值が定められるか らである.

$$
\theta_{E}+\tan ^{-1}\left(\theta_{E}+b / a\right)=\theta_{D}+\tan ^{-1}\left(\theta_{D}+c / a\right)
$$

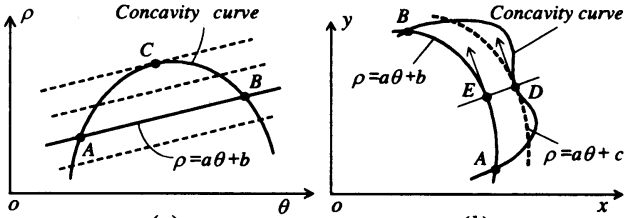

(a)

(b)

Fig. 12 Relationship between an Archimedes's spiral and a concavity curve

ここで, $\theta_{E}$ と $\theta_{D}$ はそれぞれ点 $E$ と点 $D$ の偏角である. この場合, 点 $D$ のまわりにアルキメデス蜾線 $\rho=a \theta+c$ の外側に位置する曲線の領域が存在することになる.

しかし，上述したように，これはありえないことであ る. したがって，凹曲線とアルキメデス螺線との交点 の間に法線方向距離の極大值点が存在しないことがわ かる.

一方, 曲線とアルキメデス螺線がともに連続曲線で あるので, 両者の交点 $\boldsymbol{A}$ と $\boldsymbol{B}$ との間に法線方向距離の 極值点は必ず存在する. また, 複数個の極値点が存在 すれば，それらは極小点と極大点が 1 個ずつ入れ替る 形で並ぶことになる. したがって, 点 $A$ と $B$ との間に, 凹曲線とアルキメデス螺線の法線方向距離に極值点が 1 個のみ存在し, かつ, 極小点である.

また, 図 12 の(a)におけるアルキメデス螺線 $\rho=a \theta+b$ の下側の平行線（アルキメデス螺線）に対しても，以 上の結論が同様に成立する. すなわち, 曲線との交点 の外側に位置するアルキメデス螺線 $\rho=a \theta+b$ 上に法線 方向距離の極值点が存在しない.

したがって， $\theta$ - $\rho$ 座標系における下に凹の曲線とア ルキメデス螺線との間に, 法線方向距離の極值点は 1 個しか存在せず,かつ最小值点であることがわかった.

以上と同様な方法を用いれば， $\theta$ - $\rho$ 座標系における 下に凸の曲線に対して類似する結論は導かれる。つま り，曲線の法線方向にそって，アルキメデス螺線から 曲線までの距離には，最大值点として 1 個の極値点し か存在しない.

\section{文}

（1）米田孝夫・他 2 名，非円形形状 $\mathrm{N} C$ 輪郭研削加工のため の数值解析，精密工学会誌，56-5, (1990), 867-872.

（2）米田孝夫，高能率研削加工における制御技術，精密工学 会誌, 59-9, (1993), 1443-1446.

（3）西岡雅夫，平面カムの輪郭成形法（第 1 報，直線補間制 御点の決定), 機論, 60-571, C (1994), 1047-1052.

（4）例えば，ファナック(株)，FANUC Series 16i-MB5 取扱説 明書, 1, (2001), 55-58.

（5） 丘華・他 5 名，オフセット曲線による平面カムの輪郭 加工 • 誤差影警解析, 機論, 57-541, C(1991), 2978-2984.

（6）牧野洋，自動機棫機構学，日刊工業新閆社，(1977), 28-29. 